\title{
ARCHIVNÍ PRAMENY V TRANSLATOLOGICKÉM VÝZKUMU - KDE JE HLEDAT A JAK S NIMI PRACOVAT?
}

\author{
KATEŘINA STŘEDOVÁ
}

\begin{abstract}
With a growing tendency to examine the translations in the context of their social, cultural and historical situation, translatologists must increasingly work with historical sources. Translatologists are mostly unaware of the functioning of the archival environment in which these historical sources are stored and processed. That is why this article is conceived as a presentation of the legislative rules that the researcher must follow while working in the archive, as well as the methods used to criticize and interpret the sources.
\end{abstract}

Keywords: history of translation, archival research, archival legislation and regulation, source criticism and interpretation

\section{Úvodem}

Kritický obrat v 90. letech dvacátého století přiměl translatology, aby zkoumali kulturní a sociologický kontext vzniku překladů a také jejich dopad na danou kulturu (Billiani 2007: 6). Proto se translatologové při výzkumu v oblasti dějin překladu stále častěji dostávají do situací, kdy musí kromě běžně využívaných textových pramenů, tedy především publikovaných textů, pracovat také s prameny historickými, nejčastěji archiváliemi. Tyto prameny nám mohou pomoci zasadit poznatky, které jsme už získali dříve, do širšího kontextu třeba tím, že zjistíme, $v$ jaké ekonomické a společenské situaci se objekt našeho zájmu v dané době nacházel, nebo se částečně seznámíme s dobovou překladatelskou nebo vydavatelskou praxí. Jak se však při probíhajícím výzkumu pro disertační práci ${ }^{1}$ ukázalo, metody, které se při zkoumání dějin překladu běžně používají, se zakládají především na lingvistické, literárněvědné či korpusové analýze a neposkytují pro práci s historickými prameny dostatečné nástroje, tedy takové nástroje, které by badateli umožnily vytěžit z pramenů maximum informací. Metodologie translatologického výzkumu se

1 Autorka článku v současnosti pracuje na výzkumu překladů, které vznikly v knižnici Knihy dobrých autorů založené Kamilou Neumannovou, první manželkou S. K. Neumanna. V rámci tohoto tématu se zaměřuje i na získávání informací o dobové překladatelské praxi a fungování nakladatelství K. Neumannové $\mathrm{z}$ hlediska tvorby překladů ( $\mathrm{v}$ rámci Knih dobrých autorů totiž vycházely především právě překlady aktuálních zahraničních děl). Tento výzkum je zatím v počátcích. 
samozřejmě od toho historického liší - na otázky, co zkoumáme, proč to zkoumáme a co to o zkoumaném období vypovídá, si odpovídáme jinak - přesto se při dosavadní práci na probíhajícím výzkumu potvrdilo, že i translatologové mohou při výzkumu s úspěchem využívat jak metody práce archivářů, jejichž pochopení jim usnadní orientaci v systému archivů a jejich sbírkách, a tedy snazší lokalizaci archiválií, tak historiků, jež badatelům umožňují podrobit prameny náležité kritice a interpretovat je. Ačkoli archivní badatelé obvykle využívají obou těchto perspektiv, nepodařilo se při přípravě probíhajícího výzkumu najít takové práce, které by popisovaly aplikaci metod obou těchto oborů zároveň. Právě seznámení s těmito metodami práce a s legislativním rámcem, v němž by se badatel-nehistorik měl orientovat, je cílem tohoto článku. Zároveň budou v článku uvedeny př́klady aplikace těchto metod a poznatky, které byly touto cestou v dosavadním výzkumu autorky získány.

\section{Druhy pramenů a instituce zabývající se jejich uložením a správou}

Jak už bylo výše naznačeno, při výzkumu dějin překladu většinou vycházíme ze dvou typů pramenů:

1) publikovaných textů, uložených zpravidla v knihovnách, a

2) archivních pramenů.

$\mathrm{V}$ rámci publikovaných textů, se kterými translatologové pracují nepochybně častěji a také ve větší míře, můžeme kromě samotných překladů (a jejich různých verzí) ${ }^{2}$ využít také texty, které přibližují dílo a jeho autora budoucímu čtenáři - obecně se většinou jedná o doprovodné texty neboli peritexty zahrnuté do jednoho svazku spolu s překladem, např́klad předmluvy, doslovy, poznámky překladatele, texty na předsádce nebo přebalu. $Z$ nich můžeme čerpat informace o dobovém obraze autora a jeho díla. Informace ovšem můžeme získat i z jiných typů paratextů, například z edičních plánů nakladatelství nebo zpráv avizujících vydání jednotlivých svazků (dnes bychom je označili jako marketingové texty, ačkoli se od těch současných liší zvláště stylem, který byl dříve mnohem informativnější a méně persvazivní, nicméně plnily stejnou funkci). Dobové chápání a (ne)přijetí díla v cílové kultuře pak dobře ilustrují různé metatexty, například recenze překladu, odborné, popularizační či přehledové články o autorovi a jeho díle, dílčí informace můžeme získat i z přehledových článků o literaturách určitého areálu. Nástroje pro analýzu těchto textů a zpracování získaných informací si translatologové či filologové obecně osvojují již v rámci studia na vysoké škole a pohybují se tady takříkajíc ve známých vodách.

Pro zasazení poznatků získaných z těchto analýz do dobového kontextu, fungování nakladatelského trhu či pro ověření některých informací je však vhodné nahlížet také do archivních pramenů. Zde se však badatel-translatolog často ocitá v prostředí jemu

2 Kupř́íladu v předcházejícím autorčině výzkumu se při komparaci překladů díla Osudná vejce Michaila Bulgakova, který vytvořila Alena Morávková, ukázalo jako nosné porovnávat i jednotlivá vydání téhož překladu, jelikož je dělilo od sebe mnoho let a překladatelka dělala v novějších redakcích poměrně zásadní změny (Lhotová 2015). 
zcela neznámém, a proto je na místě začít představením různých typů archivů, s nimiž se můžeme v České republice setkat:

1) veřejné archivy:

a) Národní archiv, zemské, oblastní a okresní archivy - jsou správními úřady přímo ř́zenými Ministerstvem vnitra ČR a můžeme v nich najít matriky a evidence obyvatel, v nichž můžeme ověřit data narození či úmrtí, místa pobytu, sídla firem, také tu mohou být uložené dokumentace již neexistujících podniků a institucí;

b) Archiv bezpečnostních složek - je také správním úřadem přímo řízeným Ministerstvem vnitra ČR, je možné zde najít vyšetřovací spisy, operativní svazky, fondy StB a různých složek MV ČSR;

c) archivy specializované - archivy organizačních složek státu a příspěvkových organizací (archiv Poslanecké sněmovny, Senátu, archivy vysokých škol, dále Archiv Národního muzea, Literární archiv Památníku národního písemnictví) jsou zřizovány danými institucemi a uchovávají dokumenty o jejich činnosti, např. smlouvy, výsledky činnosti v jednotlivých letech apod.;

2) soukromé archivy - spadají sem jak archivy právnických osob (divadel, nakladatelství), kde můžeme získat například informace o plánovaných představeních či knižních titulech a o procesu př́pravy těchto děl, tak i archivy dokumentů po již zesnulých osobnostech, pokud jsou zpracovávané rodinnými příslušníky. Osobní archivy však mohou být uloženy také do péče specializovaných institucí (například Literárního archivu PNP, Archivu Národního muzea či archivů univerzit, ve kterých dané osobnosti působily, apod.). Tyto fondy mohou zahrnovat takové materiály, jako jsou korespondence, deníky, různé verze a torza rukopisů.

Práce se soukromými archivy spravovanými rodinnými příslušníky se od práce s ostatními typy archivních fondů podstatně liší. Zaprvé proto, že je třeba kontaktovat pozůstalé, získat jejich souhlas se zpřistupněním archiválií a dohodnout se s nimi na podmínkách využívání archivu (i to upravuje $\$ 41$ odst. 1 zákona č. 499/2004 Sb., o archivnictví). Zadruhé se míra zpracování těchto archiválií velmi liší - od pouhého uložení v krabicích bez jakéhokoli tematického či časového roztř́íění až po podrobnou evidenci, ve které může být popsaný i každý jednotlivý dokument. Jelikož má práce se soukromými archivy mnoho specifik, zpř́istupnění archiválií (či naopak omezení prrístupu k nim) závisí především na domluvě badatele se správcem takového souboru a žádný takový fond dosud nebyl předmětem našeho výzkumu, budeme se v dalších odstavcích zabývat spíše pravidly práce ve veřejných archivech.

\section{Metody získání přístupu k archiváliím}

V této kapitole bude $\mathrm{v}$ úvodu popsána práce s archivními materiály obecně a její legislativní pozadí, dále zde budou představeny nepostradatelné zdroje informací, takzvané archivní pomůcky, a v poslední části bude na poznatcích z probíhajícího výzkumu ukázáno, jaký význam mohou tyto informace mít při volbě tématu, stanovení časové náročnosti plánovaných návštěv archivů a v dalších pragmatických aspektech výzkumu.

Při tomto výzkumu se ukázalo - a platí to pro archivní výzkum obecně -, že je zásadní zjistit hned v počátcích, ve kterých institucích by mohly být relevantní dokumenty ulo- 
Žené (jak tato zjištění ovlivnila postup samotného výzkumu, bude popsáno v části 2.3). Proto bude nejdřive představen obecný postup, který jsem vyabstrahovala z cenných rad zkušených archivních badatelù. ${ }^{3} \mathrm{~V}$ době digitalizace je v tomto ohledu velmi nápomocný portál archivních fondů a sbírek České republiky ${ }^{4}$, který sdružuje informace o archivních fondech a sbírkách muzeí, a oficiální databáze archivních fondů a sbírek dostupná z webu Ministerstva vnitra ČR ${ }^{5}$. Na základě informací získaných v těchto databázích je vždy třeba kontaktovat příslušný archiv - v současnosti badatelé nejčastěji navštíví jeho internetové stránky a na základě postupu uvedeného přímo na stránkách nebo v badatelském řádu kontaktují pracovníky archivu (např. prostřednictvím elektronické pošty) a vyžádají si potřebné materiály ke studiu do badatelny. Během výzkumu se ukázalo jako velmi cenné, že př̀i návštěvě webových stránek může badatel také zjistit, zda jím požadované dokumenty nejsou již dostupné prostřednictvím tzv. digitální badatelny. V té bývají zpřístupněné nejčastěji požadované archiválie (např. matriky, kroniky apod.), které se již archivu podařilo digitalizovat a které tedy dnes mohou badatelé studovat i online. Je tedy doporučeníhodné důkladně prostudovat internetové stránky a digitalizované zdroje předtím, než archiv kontaktujeme.

\subsection{Důležitá ustanovení legislativy}

Pokud po prozkoumání internetových databází a stránek zjistíme, že potřebné prameny zatím digitalizovány nebyly a je třeba navštívit archiv osobně, je zmíněný badatelský řád jedním ze dvou základních předpisů, se kterými je dobré se seznámit ještě před cestou do archivu. Druhým, upravujícím práci všech archivů obecně, je zákon č. 499/2004 Sb., o archivnictví a spisové službě, ve znění zákona č. 250/2014 Sb. (dále jen „archivní zákon“ nebo zkráceně „AZ“). Pro badatele nejdůležitější ustanovení tohoto zákona budou představena dále. Znění badatelských řádů vychází ze souvisejícího právního dokumentu Z ustanovení vyhlášky č. 645/2004 Sb., novelizované vyhláškou č. 213/2012 Sb., která je prováděcím dokumentem k archivnímu zákonu (dále jen „archivní vyhláška“). Konkrétní podoba badatelského řádu daného archivu se ale může v některých bodech lišit, proto je třeba si důkladně projít badatelský řád každého archivu, který badatel hodlá navštívit. Odlišná mohou být především pravidla práce v badatelně (např. jaké pomůcky a př́istroje si smí badatel do badatelny přinést, zda musí s archiváliemi pracovat v rukavicích apod.) či lhůty pro vydávání materiálů, které se odvíjejí především od toho, kolika pracovníky archiv disponuje a kolik badatelů archiv v průměru navštěvuje (je to tedy, dle našich dosavadních zkušeností, dáno zcela praktickými hledisky, např́iklad tím, kolik kartonů jsou pracovníci schopní denně připravit a následně od badatelů opět převzít a zkontrolovat).

Archivní zákon upravuje mimo jiné výběr a evidenci archiválií, práva a povinnosti jejich vlastníků, držitelů a správců, skartační řízení i působnost Ministerstva vnitra a dalších správních úřadů na úseku archivnictví. Proto je záměrem tohoto oddílu představit

3 Zde musím poděkovat za rady pracovníkům Literárního archivu Památníku národního písemnictví (dále jen PNP) a také členům Ještědské pobočky České archivní společnosti. Rozdílům v translatologickém a historiografickém přístupu k problematice využívání archivních materiálů ve výzkumu se věnuje článek Středová 2019.

4 Dostupný z: http://www.badatelna.eu/ (access: 30. 3. 2019).

5 https://aplikace.mvcr.cz/archivni-fondy-cr/Default.aspx (access: 30. 3. 2019). 
zájemcům o archivní výzkum pouze hlavní ustanovení, která se k archivnímu výzkumu vztahují.

Dle $\$ 41$ odst. 2 AZ je bezplatné jak nahlížení do archiválií náležejících do péče veřejných archivů (výjimku tvoří audiovizuální archiválie v péči Národního filmového archivu), tak př́istup do prostor veřejných archivů určených k nahlížení do archiválií, tj. obecně badatelen. Archiv však může dle $\$ 40$ odst. $5 \mathrm{AZ}$ požadovat úhradu nákladů souvisejících s pořízením „výpisu, opisu nebo kopie archiválie v analogové podobě anebo s pořízením repliky archiválie v digitální podobě, spojených s vyhledáním archiválií a jejich dalším zpracováním, nebo s pořízením rešerše $\mathrm{z}$ archiválií. Výše těchto poplatků se rrídí ceníkem poskytovaných služeb, který je archiv povinen zveřejnit. Podle našich zkušeností je však velmi důležité vědět o možnostech využití těchto služeb, zvláště o možnosti zpoplatněného vyhledání materiálů nebo zpracování rešerší. Tyto služby archivů mohou velmi pomoci v př́padě, že jsou prameny badatelům běžně nepřístupné (viz níže) nebo jsou uložené ve velmi vzdálených archivech a není jisté, na kolik jsou pro výzkum skutečně nosné. Při publikaci snímků archiválií je zpravidla třeba požádat daný archiv ještě o souhlas s jejich uveřejněním a často objednat kvalitní reprodukci, kterou archiv také zpoplatní dle uvedeného ceníku. Samozřejmou podmínkou publikování je náležitá citace použitých pramenů.

Ve veřejných archivech může být badatelům umožněn přístup pouze $\mathrm{k}$ dokumentům starším 30 let (není-li př́istup k dané archiválii omezen kvưli některému $\mathrm{z}$ důvodů uvedených v následujícím odstavci) a $\mathrm{k}$ archiváliím, které již byly zveřejněny ( $\$ 37$ odst. $1 \mathrm{AZ}$ ). Dále jsou dle odstavců 10-11 \$37 AZ a zákona o Ústavu pro studium totalitních režimů a o Archivu bezpečnostních složek ${ }^{6}$ prrístupné ty dokumenty mladší 30 let, které vznikly před 1 . lednem $1990 \mathrm{z}$ činnosti státních orgánů, vojenských soudů, prokuratur a bezpečnostních složek. Zpřístupnit je možné i ty archiválie, jejichž obsahem jsou demografické a statistické soubory dat, pokud lze osobní údaje před nahlížením anonymizovat $(\$ 37$ odst. 12 AZ).

Přístup k archiváliím však může být dle $₫ 38$ AZ odepřen, především pokud nahlížení neumožňuje stav archiválií, stav jejich zpracování nebo pokud obsahují citlivé údaje fyzické osoby, která neudělila souhlas s nahlížením nebo podala námitku proti nahlížení (poslední omezení neplatí v případě zmíněných archiválií z doby „nesvobody“ upravených odstavci 10-11 \$37 AZ). V případě nezpracovaných archiválií lze výjimečně umožnit přístup vědeckým pracovníkům nebo studentům „na základě žádosti doložené písemným potvrzením kulturně vědecké instituce o naléhavém časově limitovaném vědeckém nebo výukovém účelu nahlíženi" ( $\$ 38$ odst. $4 \mathrm{AZ}$ ).

Žádost o nahlížení do archiválií se dle $₫ 35$ odst. 3 AZ podává na badatelském listu. $\mathrm{V}$ něm musí badatel uvést osobní údaje, jež následně pracovník archivu ověří na základě průkazu totožnosti, který je badatel povinen na vyzvání předložit. Pokud badatel není schopen prokázat svou totožnost, bude mu nahlížení do archiválií odepřeno (čl. 1 odst. 3-4 vzorového badatelského řádu, který tvoří prŕílohu $3 \mathrm{k}$ archivní vyhlášce). Žadatel je také povinen v listu uvést účel studia archiválií, přičemž: „Informace získané z archiválií užívá badatel jen k účelu uvedenému v badatelském listu“ (tamtéž čl. 3 odst. 5). V praxi se

6 Zákon č. 181/2007 Sb., o Ústavu pro studium totalitních režimů a o Archivu bezpečnostních složek a o změně některých zákonů, ve znění zákona č. 167/2012 Sb. 
ovšem, například v Národním archivu nebo Literárním archivu PNP, pro prvotní objednání dokumentů do badatelny vyplňují žádanky či objednací lístky, které žadatel může zaslat pracovníkům i elektronickou poštou. Poté je mu oznámeno, odkdy bude mít archiválie připravené v badatelně. Teprve při návštěvě archivu pak vyplňuje badatelský list.

Ve chvíli, kdy archiv badateli zpř́stupní požadované archiválie, pracovníci archivu mu připraví archiválie v množství a lhůtách upravených badatelským řádem archivu, jak již bylo zmíněno výše. Technické požadavky na prostory archivu včetně badatelny, která musí být dle $\$ 61$ odst. 3(c) AZ zrrízena ve všech veřejných a akreditovaných soukromých archivech, upravují některá ustanovení archivního zákona. Podle $\$ 61$ odst. 5(c) AZ musí například vybavení badatelny umožňovat používání přenosných prostředků výpočetní techniky a podle písmene a) téhož odstavce musí být archiv vybaven zařízením na pořizování kopií, př́padně také čtecími zařízeními na mikrofilmy, pokud je archiv spravuje. Na základě zkušeností z probíhajícího výzkumu je zřejmé, že toto vybavení badatelům práci velmi usnadňuje a zkracuje množství času strávené v badatelnách. Na základě žádosti totiž archivy většinou umožňují použití i vlastních fotoaparátů či přenosných skenerů. Není proto třeba vypisovat všechny potřebné údaje z relevantních dokumentů a je možné se při návštěvě archivu více věnovat procházení předložených sbírek a vyhledávání vhodných materiálů.

\subsection{Orientace v archivních sbírkách, archivní pomůcky}

Při orientaci $\mathrm{v}$ archivních sbírkách pomáhá znalost archivní vyhlášky, především její přílohy č. 2, v níž jsou popsány druhy archivních pomůcek. Archivní pomůcky jsou výsledkem snahy archivářů zpřístupnit spravované fondy badatelům; nejběžnějším typem jsou inventáře. Do analogové podoby pomůcek může badatel nahlížet v prostorách badatelny, v elektronické podobě jsou popisy archivních sbírek dostupné v oficiální databázi archivních fondů a sbírek na stránkách MV ČR ${ }^{7}$ nebo přes portál badatelna.eu. Elektronické popisy jsou však podle dosavadních zkušeností méně podrobné než údaje v analogových inventářích, kupříkladu Národní archiv u svých sbírek v elektronických evidencích uvádí inventární číslo, původní označení archiválií (např. číslo jednací nebo signaturu), obsah, dataci a evidenční jednotku/y. ${ }^{8}$ Oproti tomu u analogového inventáře by dle čl. 2.2 př́lohy č. $2 \mathrm{k}$ archivní vyhlášce měl být na každém titulním listu inventáre mimo jiné uveden: název archivu a archivní pomůcky, časový rozsah archivního souboru (přesto musí přesnější dataci jednotlivých archiválií mnohdy určit badatel po podrobném prostudování, viz níže), jméno zpracovatele i místo a rok vyhotovení archivní pomůcky. Úvod inventáře dále obsahuje kapitoly popisující vývoj (u právnické osoby) či životopis původce (tj. toho, z jehož činnosti dokument vznikl) ${ }^{9}$ a vývoj a dějiny archivního souboru (případně informace o ztrátách dokumentů či vyřazení duplikátů apod.), dále stručný rozbor souboru a záznam o jeho uspořádání. V tiráži inventáře na poslední straně pomůcky je možné zjistit také počet evidenčních jednotek zpř́stupněných touto pomůckou a rozsah zpřístupněných archiválií v běžných metrech.

7 https://aplikace.mvcr.cz/archivni-fondy-cr/Default.aspx (access: 30. 3. 2019)

https://www.nacr.cz/fondy-a-pomucky/vyhledavani/ (access: 30. 3. 2019)

9 Díky jinému pohledu historika mohou být uvedené informace o historii původce pro badatele-translatologa velmi cenné a nasměrovat jej také $\mathrm{k}$ dalším zdrojům informací, především $\mathrm{k}$ těm, ze kterých čerpal tvůrce pomůcky. 
Právě poslední zmíněné informace o počtech jednotek a rozsahu archiválií v běžných metrech jsou velmi důležité pro to, aby si badatel dokázal udělat na základě pomůcky představu o tom, jak velké množství archiválií daný soubor obsahuje. V případě nezpracovaných archiválií je hlavní evidenční jednotkou „karton“ ( $\$ 3.7$ př́lohy č. 1 k archivní vyhlášce) neboli speciální, normovaná archivní „krabice s archivními (registraturními) spisy zpravidla téže registraturní značky nebo téhož registraturního oddělení“ (Rameš 2005: 109), tedy obsahující dokumenty pouze z jednoho souboru zaevidované jako jedno nebo více inventárních čísel. U zpracovaných archiválií je pak hlavní evidenční jednotkou „fascikl“ ( $\$ 3.8$ př́lohy č. 1 k archivní vyhlášce), tedy obsáhlejší svazek spisů z jednoho souboru zaevidovaných jako jedno nebo více inventárních čísel (Rameš 2005: 75). Druhý uvedený údaj - běžný metr neboli metráž - v archivnictví označuje jeden metr těsně vedle sebe vyskládaných stojících kartonů/krabic. ${ }^{10}$ Kombinace obou údajů dává badateli základní přehled nejen o množství dokumentů v daném souboru, ale také o podrobnosti jeho zpracování. ${ }^{11}$ Např́íklad v Literárním archivu PNP se můžeme setkat s velmi podrobnou evidencí, která uvádí i počty jednotlivých listů (také je např̀ u korespondence uvedeno, kdo je odesílatelem a kdo adresátem).

Informace o původním uspořádání sbírky mohou zase v některých př́ípadech pomoci při určování pořadí, ve kterém dokumenty vznikly. Bohužel v př́padě fondu K. Neumannové nebylo z níže popsaných důvodů možné podobná vodítka využít.

\subsection{Pragmatické aspekty výzkumu činnosti nakladatelství K. Neumannové}

V této části bude na příkladu výzkumu činnosti nakladatelství Kamily Neumannové působícího na přelomu devatenáctého a dvacátého století předvedeno, jak může znalost a pochopení metod a způsobu práce archivářů pomoci badateli při lokalizaci materiálů, efektivním rozvržení výzkumu a předběžném ocenění nosnosti dostupných materiálů.

Prvotní průzkum archivních sbírek pomocí dostupných elektronických databází ukázal, že se materiály vztahující se ke jménu Kamily Neumannové nacházejí převážně v Literárním archivu PNP a jednotliviny také v Národním archivu. Tyto informace byly velmi důležité $\mathrm{z}$ hlediska plánování výzkumu, jelikož naznačovaly, že většinu výzkumu bude možné provést v Praze a nebude tedy třeba dojíždět do vzdálenějších archivů, což znamenalo, že nebude nezbytně nutné shánět grantové prostředky na uhrazení cestovních výloh. Tyto informace byly příznivé, na druhou stranu nepř́iznivé byly bližší údaje o materiálech uložených $\mathrm{v}$ Literárním archivu PNP získané z velké části také již při průzkumu elektronických databází. Ve sbírce Neumannová Kamila (č. sbírky 1183) je totiž uloženo pouze 30 kusů korespondence, $\mathrm{z}$ toho 28 kusů korespondence přijaté od 17 různých odesílatelů a 2 kusy korespondence odeslané Neumannovou neznámým adresátům, nebylo tedy možné předpokládat, že bychom zde našli větší část komunikace s některým $\mathrm{z}$ autorů či spolupracovníků. Popis fondu a inventář (edice inventářů č. 313) objasňují fragmentárnost sbírky - nejedná se totiž o ucelenou pozůstalost, ale o materiály získa-

10 Tyto krabice podobné šanonům se skládají hřbety dopředu tak jako knihy v knihovně.

11 Pokud např́íklad víme, že soubor číá několik běžných metrů, zároveň ale jen pár evidenčních jednotek, je zřejmé, že je zpracování spiše méně podrobné a jednotlivé jednotky obsahují větší množství dokumentů, tudíž i orientace v souboru bude pravděpodobně složitější. 
né jednotlivými nákupy a dary. Žádnou společnou korespondenci bohužel neobsahuje ani sbírka Procházka Arnošt (č. sbírky 1361), v níž je uložena pozůstalost po nejbližším spolupracovníkovi Neumannové a šéfredaktorovi jejího nakladatelství. Velmi malá část jejich vzájemné korespondence (pouze 4 kusy) se dochovala ve sbírce č. 741 Karáskova galerie, tedy ve sbírce korespondencí významných osobností shromážděné Jiřím Karáskem ze Lvovic, který v nakladatelství publikoval své básně. Ani sbírky pozůstalostí dalších spolupracovníků bohužel podle dosavadních zjištění neobsahují větší množství pramenů, které by mohly poodhalit způsob fungování tohoto nakladatelství. Trochu slibnější se podle úvodního průzkumu zdály být pouze pozůstalosti po překladateli Alfonsi Breskovi (č. 130), obsahující kromě pár kusů korespondence také překladatelovy deníky, a po knihovníkovi a knihtiskaři Josefu Portmanovi (č. 1340), v níž je uloženo ve srovnání s ostatními fondy neuvěřitelných 97 kusů korespondence s nakladatelkou, ovšem katalog neuvádí téma této korespondence a může se tedy jednat i o dopisy ryze osobní povahy. Bohužel se doposud kromě sbírky Kamily Neumannové a další části její korespondence uložené ve sbírce Lešehradeum (č. 983) nepodařilo projít žádný další z objevených fondů, protože jsou všechny dokumenty psané ručně a rukopis mnohých pisatelů vyžadoval poměrně náročné dešifrování (dobové psací písmo se od dnešního zjevně odlišovalo), než se podařilo odhalit obsah těchto dopisů a pohlednic. Je třeba zde říci, že archivní výzkum je právě z těchto důvodů velmi časově náročný.

Z popsaného úvodního průzkumu provedeného z části pomocí elektronických zdrojů, $\mathrm{z}$ části studiem inventárư $\mathrm{v}$ Literárním archivu PNP vyplynulo důležité zjištění, totiž že se zřejmě nepodaří získat tolik nosných historických pramenů, aby bylo možné zrekonstruovat ucelenější obraz fungování nakladatelství z hlediska produkce překladové tvorby, tedy výběru titulů, honorářủ, redakční praxe apod. ${ }^{12}$ Toto zjištění umožnilo už v poměrně časné fázi práce přehodnotit dosavadní návrh výzkumu a doplnit jej o návrh korpusové analýzy překladů z ruštiny, které v tomto nakladatelství vyšly. Ta by se měla zaměřit na nešvary, které dobová kritika vyčítala především překladům Arnošta Procházky (blíže viz Levý 1957), a odhalit, zda byly tyto překladatelské postupy vlastní i jiným překladatelům působícím $\mathrm{v}$ tomto nakladatelství.

\section{Kritika a intepretace archivních pramenů}

Jak bylo popsáno v závěrečné části předchozí kapitoly, v př́ípadě Kamily Neumannové a jejího nakladatelství se nedochovalo mnoho nosných historických pramenů. Proto je nutné tyto materiály studovat o to pečlivěji a kritičtěji. Následující kapitola se právě $\mathrm{z}$ tohoto důvodu zaměří na kritiku a interpretaci archivních materiálů. V některých aspektech bude popsána aplikace těchto metod při probíhajícím výzkumu.

Ačkoli mohou být při interpretaci archivních pramenů užitečné i metody textové analýzy, které translatologové běžně používají při interpretaci jiných textů, je pro získání maxima obsažených informací třeba tyto prameny podrobit i dalším historickým analýzám. V prvé řadě je to takzvaná vnější kritika, jejímž cílem je zjistit autenticitu pramene,

12 Základní údaje o nakladatelství a jeho historii byly již popsány Zachem (1976) a také v hesle Kamila Neummanová, které tento autor zpracoval pro Lexikon české literatury (2000). 
ověřit nebo určit jeho dataci a autorství či vyjasnit situaci, která vedla k jeho vzniku. Od ní badatel přechází k vnitřní kritice zaměřené na ocenění obsahu (tj. míry přesnosti odrazu historické skutečnosti), motivů autora a určujících faktorů (Kvaček 1985: 168) a následně i k interpretaci.

\subsection{Datace a místo vzniku}

Údaje o čase a místě vzniku bývají často zaznamenány přímo na daném dokumentu (př́padně může být u dopisu datum uvedeno v razítku na obálce), někdy ale tyto údaje chybí, nebo mohou být nesprávné. Kvaček uvádí, že údaje mohou být nepřesné nezáměrně, nebo úmyslně (např. v př́padech falza nebo tvưrců ukrývajících se před represivním aparátem). Proto je třeba posuzovat i místo a okolnosti nálezu, dobový jazyk, zmínky o událostech či osobách (Kvaček 1985: 168-170). Pokud text například obsahuje údaje o měnách nebo měrných jednotkách, může badatel hledat informace o tom, kdy se dané měny či jednotky užívaly, v příručkách o numismatice či historické metrologii. Podobně pokud se jedná o starší typ úředního dokumentu, bližší informace (včetně časového určení) může poskytnout jiný obor pomocných věd historických - diplomatika.

$\mathrm{V}$ př́padě dopisů uložených $\mathrm{v}$ pozůstalosti Kamily Neumannové je určení a ověření datace obzvlášt důležité, a to $\mathrm{z}$ několika důvodů. Především je to dáno fragmentárností sbírky, kdy máme k dispozici vždy jen jednu stranu komunikace - zpravidla dopis či pohlednici adresovanou Neumannové. Nadto jsou tyto části korespondence osamocené a není možné kontext či bližší dataci určit ani podle předcházejících či následujících dopisů od daného pisatele. Jediné, na co se tedy badatel může alespoň částečně spolehnout, jsou poštovní razítka. V případě pohlednic či korespondenčních lístků je tento údaj poměrně jasně určující, ale v prrípadě dopisů, které jsou zpravidla nedatované, je třeba ověřit to, že obálka skutečně patří $\mathrm{k}$ danému dopisu a nedošlo tedy v minulosti k nějaké záměně. Toto ověření se v některých př́ípadech podařilo díky zmínkám o chystaných či nedávno vydaných publikacích a jiných událostech, které po srovnání s údaji uvedenými v soupise edičního díla nakladatelství (Zach 1976) a Souborném katalogu ČR umožnily dataci potvrdit.

\subsection{Určení autorství}

U zpracovaných fondů badatel zpravidla zná původce. V př́ípadě velmi podrobné evidence v Literárním archivu PNP, podle mých zkušeností, dokonce často ví už z internetové databáze, kdo je pisatelem a kdo adresátem předložené korespondence, a může si vyžádat jen ty její části, které jsou pro něj relevantní. Jak ale Kvaček vhodně upozorňuje, mnohdy je určení autorství složitým až nesplnitelným úkolem. V některých případech však stačí znát instituci, sociální okruh nebo ideové prostředí, v němž archiválie vznikla (Kvaček 1985: 169). Čím více toho ale badatel o autorovi ví, tím spíše může zjistit a ověřit, zda mohl být přímým svědkem událostí, které jsou v dokumentu popisovány, nebo zda je zaznamenal podle informací od jiných aktérů nebo podle nějaké jiné písemnosti (Kvaček 1985: 171). Na tyto poznatky může badatel navázat vnitřní kritikou, kdy analyzuje například motivaci pisatele či faktory, které vedly k sepsání informací právě v této podobě. Důležité je také postavení autora v dobových společenských strukturách, jeho pozorovací 
a vyjadřovací schopnosti, vzdělání, pracovní zařazení, funkce a vztah ke konkrétní moci a jejím institucím, což jsou faktory, které sleduje i sociologie překladu inspirovaná díly Pierra Bourdieuho ${ }^{13}$ (i proto je Kvačkův text pro badatele-translatology stále nosný).

Také určení autorství je v případě korespondence Neumannové problematické, většina dopisů je totiž opatřena nečitelným nebo nerozluštitelným podpisem. Naštěstí jsou fondy uložené v Literárním archivu PNP dobře zpracované a jméno odesílatele, pokud se jej podařilo pracovníkům zjistit, bývá uvedeno na složce/obálce, v níž je daný kus korespondence uložen. U některých materiálů se podařilo takto uvedené autorství ověřit opět na základě zmínek o chystaných či nedávno vydaných publikacích nebo na základě porovnání rukopisu s jinými dochovanými dopisy pisatele, na nichž je podpis čitelnější.

\subsection{Textová kritika}

Díky zkušenostem mají translatologové v oblasti textové analýzy oproti historikům určitou výhodu, protože jsou zběhlí v analyzování textů i v práci se slovníky. Textová kritika se využívá už při vnější kritice, tedy v průběhu ověřování autenticity pramene jednak při určování datace na základě zvoleného jazyka, jednak při určování návaznosti dokumentů (např́iklad který z dokumentů je předběžnou a který je konečnou verzí) a jejich závislosti na okolnostech (například skrze citované nebo parafrázované pasáže) (Kvaček 1985: 171-172).

Při vnitřní kritice se textová analýza využívá pro analýzu výrazových prostředků a celkové výstavby textu, především vlivu formy daného typu textu na obsah (je totiž třeba odlišit dobové konvence od skutečné informační hodnoty) (Kvaček 1985: 173). Důležité je také odlišení informací, které pramen sděluje záměrně, od těch nezáměrných a také jejich př́ípadného zkreslení.

Příklady takové nezáměrně sdělené informace můžeme najít např́iklad v korespondenčním lístku od Josefa Čapka. Čapek v něm Neumannovou prosí, aby zaslala Karlu Sezimovi, recenzentovi časopisu Lumír (vl. jménem Karel Kovář), ještě jeden recenzní výtisk Čapkovy knihy Lelio. Čapek zde zřejmě ne zcela záměrně odhaluje zákulisní informace $z$ redakce časopisu Lumír, když píše: „Pan Sezima by napsal velmi rád referát o mé knize do ,Lumíra', ale stěžoval si, že z publikací, došlých na redakci Lumíra nic na něho nezbyde, že zmizejí dříve, než se o ně může jako referent zajímati. "14 Sezima tedy svou žádost, kterou Čapek tlumočí, nezdůvodnil jedním př́ípadem, kdy na něj výtisk nezbyl, ale obecnou praxí redakce slavného časopisu, kterou takto Čapek odhaluje. Je však důležité mít na paměti to, že se jedná o informaci zprostředkovanou. Pokud bychom $\mathrm{z}$ takové informace chtěli vyvozovat nějaké závěry, bylo by tř̌eba ji ověřit v dalších zdro-

13 Bourdieuova základní díla Teorie jednání a Pravidla umění byla přeložena do češtiny v letech 1998, respektive 2010. Zahraniční badatelé zabývající se vlivem cenzury na překladovou produkci (např̀ Billiani 2007) vycházejí také z knihy Distinction (1984).

14 Literární archiv Památníku národního písemnictví, sbírka č. 1183 Neumannová Kamila, fascikl Čapek Josef, korespondenční lístek J. Čapka K. Neumannové ze dne 8. 11. 1917 „odpustte, že Vás znovu...“ (Jelikož norma ISO 690:2011 citace archivních dokumentů neupravuje, vycházím z článku N. Urbánkové „Jak správně citovat aneb Komentář k ČSN ISO 690“ (2003), která doporučuje uvádět údaje v pořadí od nejobecnějšího $\mathrm{k}$ nejkonkrétnějšímu, tedy: název archivu, název fondu, číslo kartonu /fasciklu/mapy apod. Př́íklady citování je možné dohledat také na internetu např. https://sites.google .com/site/novaiso690/schema-a-priklady/archivlie-p [access: 30. 3. 2019]) 
jích. Zároveň ale Čapkův lístek poskytuje důležitý vhled do praxe samotného nakladatelství Neumannové - totiž, že si autoři sami sháněli recenze svých děl (dále v lístku ještě vyjmenovává, že mu recenzi přislíbili také Arne Novák či Miroslav Rutte). Tato praxe byla pravděpodobně obvyklá, protože podobné zmínky byly nalezeny také v dopisech od Jiřího Karáska ze Lvovic, uložených ve sbírce Neumannové15. V obou prrípadech se však jedná o původní díla českých autorů, nikoli o překlady. Zda se tedy i překladatelé museli zasazovat o propagaci vlastní práce podobně jako samotní autoři, zatím není zřejmé.

\subsection{Interpretace pramenů}

V této fázi Kvaček upozorňuje na to, že je při posuzování a výkladu nutné hodnotit pramen jako celek a nevkládat do něj nic, co by jej odlučovalo z doby vzniku, z jeho časových a věcných spojitostí (1985: 174). Je tedy třeba vyhnout se interpretování skutečností pohledem jiné doby.

U textových pramenů je nutné důkladně celý text přečíst. To může být, jak už bylo naznačeno, problematické i u dokumentů z počátku dvacátého století (u ještě starších typů písem může pomoci obor pomocných věd historických - paleografie). Pro pochopení dobových významů slov se při probíhajícím výzkumu ukázalo jako nezbytné pracovat se slovníky - dosud nejobsáhlejší a v našem výzkumu nejvyužívanější pomůckou při dohledávání dobové sémantiky je Př́ruční slovník jazyka českého, ${ }^{16}$ který obsahuje i výrazy užívané v druhé polovině 19 . století; hodit se může ale i etymologický slovník. ${ }^{17}$

Interpretace vyžaduje také orientaci v dobových reáliích. Při ní mohou badateli pomoci kromě zmíněné numismatiky, diplomatiky či historické metrologie také biografické slovníky osobností určitého oboru, staré mapy nebo např́klad Slovník pro historiky a návštěvníky archivů (Rameš 2005), který kromě výkladů o různých institucích a typech dokumentů obsahuje i stručný německo-český slovníček často užívaných pojmů, což je při studiu období přelomu devatenáctého a dvacátého století užitečné. Při zkoumání dějin překladu je však zároveň nutné znát dobový kontext v českém literárním dění. Základní příručkou by pro badatele mohla být publikace Česká literatura od počátkư $k$ dnešku (Lehár 2008). V případě Neumannové jsou však nosnější spíše práce odborníků zabývajících se vývojem knižního trhu jako výše zmíněná Zachova práce (1976) a jeho heslo v Lexikonu české literatury (Opelík 2000), což je oblast, které se většina literárních historiků nevěnuje. Zachovy práce jsou vedle informací prrímo o činnosti Neumannové zásadní i tím, že v nich najdeme vysvětlení dobového významu takových pojmů, jako je „autorizovaný překlad“, tedy překlad schválený autorem, což byl na začátku dvacátého století projev snahy kvalitních nakladatelů, jak poctivé překlady odlišit od množících se překladů nekvalitních. Proto se s tímto spojením či jeho variacemi můžeme často setkat v tirážích dobových překladů - např́klad u knih vydaných K. Neumannovou bývá uvá-

15 Například: Literární archiv Památníku národního písemnictví, sbírka č. 1183 Neumannová Kamila, fascikl Karásek ze Lvovic Jiří, korespondenční lístek J. Karáska K. Neumannové ze dne 2. 12. 1912 „... nezapomeňte poslati ,Ostrov vyhnancư té Studentské revui...".

16 Dnes $\mathrm{k}$ němu mají badatelé snadný př́istup přes webové rozhraní https://bara.ujc.cas.cz/psjc/search .php (access: 30. 3. 2019). Historickou češtinu pak zprostředkovává Vokabulář webový dostupný z http://vokabular.ujc.cas.cz/ (access: 30. 3. 2019).

17 Aktuálně nejnovějším je 3. vydání Českého etymologického slovníku J. Rejzka. 
děno „za souhlasu autora přeložil...“ (o to smutnější je, že se nám žádná z těchto korespondencí nakladatelky s pưvodními autory nedochovala).

Při interpretaci je třeba se zaměřit také na původní funkci textu (informativní, persvazivní, estetickou apod.). Pokud pramen nese prvky umělecké tvorby, je translatolog-badatel oproti historikům do jisté míry ve výhodě (například díky znalosti práce s básnickými figurami). Přesto musí mít na paměti, že interpretuje historické prameny, tedy že „obsah slov je třeba posuzovat historicky, v souvislostech jejich použiti““ (Kvaček 1985: 174).

K problematice interpretace Kvaček na závěr dodává, že výpověd' pramene bývá rozsáhlejší, když se badatel při práci s ním opírá o širší znalosti, které si předem nastudoval (Kvaček 1985: 175). Jinými slovy, čím více informací o dané době a kontextu badatel předem ví, tím více je schopen z pramene vytěžit. Zkušenosti z praxe tuto zásadu potvrzují. $\mathrm{V}$ př́padě korespondence Kamily Neumannové bylo velmi užitečné se dopředu důkladně seznámit s edičním soupisem tohoto nakladatelství, a to jak ve formě zpracované Zachem (1976), tak i v Souborném katalogu České republiky. Mnozí pisatelé totiž v dopisech názvy knih zkracovali nebo mírně pozměňovali a bez této předchozí znalosti by bylo dešifrování korespondence často téměř nemožné.

\section{Závěr}

Prostředí archivů je pro většinu badatelům $\mathrm{z}$ řad translatologů neznámé. Cílem tohoto článku proto bylo přinést zájemcům o studium archivních pramenů základní informace o práci s archiváliemi a o metodách jejich zpracování. Na začátek byly obecně přiblíženy zdroje informací, které může badatel při výzkumu dějin překladu použít. Ty z nich, které jsou využívány častěji, byly pouze zmíněny, zatímco méně časté zdroje byly popsány trochu blíže. Archivní materiály mohou badatelům v tomto směru posloužit především jako zdroje poznatků o dobové praxi, at už překladatelské, nebo nakladatelské, a zasadit tak poznatky o samotných textech překladu nebo jejich tvưrcích do širšího kontextu.

V textu byla shrnuta také důležitá ustanovení platné legislativy, kterými se archivy a práce $\mathrm{v}$ nich řídí a která upravují práva a povinnosti badatele při žádosti o přístup $\mathrm{k}$ archiváliím i př̀ jejich následném studiu. Pro usnadnění orientace v organizaci archivních sbírek tu byly přiblíženy také nejběžnější archivní pomůcky.

Třetí tematický oddíl pak popisuje metody práce s archivními prameny, především jejich kritiku a interpretaci. Během fáze kritiky pramenů musí badatel především zjistit autenticitu pramenů (tedy zda záměrně, či nezáměrně neuvádí nepravdivé údaje), teprve poté může analyzovat obsažené informace, zasadit je do kontextu dalších dokumentů a předchozích poznatků o daném tématu. Během kritiky i interpretace může badatel-translatolog dobře využít své dovednosti v oblasti textové analýzy.

Na závěr je třeba říci, že i když věnujeme předběžnému studiu internetových databází a archivních pomůcek mnoho času a úsilí, může se stát, že se po projití desítek listů úředních dokumentů nebo korespondence ve výzkumu nikam neposuneme. Ze zkušeností se zvláště u korespondence můžeme setkat s tím, že si mnohé osobnosti (nebo adresáti jejich dopisů) ponechaly především osobně laděné dopisy, ze kterých vyčteme různé zajímavosti, ale jen málokdy informace, které by osvětlovaly jejich profesní život. 


\section{BIBLIOGRAFIE}

Billiani, Francesca (ed.) (2007) Modes of censorship and translation: national contexts and diverse media, Manchester: St. Jerome Pub.

Bourdieu, Pierre (1984) Distinction. A Social Critique of the Judgement of Taste, London: Routledge \& Kegan Paul.

Bourdieu, Pierre (1998) Teorie jednání, vyd. 1. Praha: Karolinum.

Bourdieu, Pierre (2010) Pravidla umění: geneze a struktura literárního pole, vyd. 1., Brno: Host.

Čapek, Josef (8. 11. 1917) „odpustte, že Vás znovu... “ [korespondenční lístek] Literární archiv Památníku národního písemnictví, sbírka č. 1183 Neumannová Kamila, fascikl Čapek Josef. Praha

Karásek ze Lvovic, Jiří (2. 2. 1912) „...nezapomeňte poslati ,Ostrov vyhnancư té Studentské revui... “ [korespondenční lístek] Literární archiv Památníku národního písemnictví, sbírka č. 1183 Neumannová Kamila, fascikl Karásek ze Lvovic Jiř́. Praha

Kvaček, Robert (1985) 'Kritika a interpretace pramenů’, in Hroch, Miroslav (ed.) Úvod do studia dějepisu. 1. vyd., Praha: Státní pedagogické nakladatelství, 168-175.

Lehár, Jan (ed.) (2008) Česká literatura od počátků k dnešku, 2., dopl. vyd. [i.e. 3. vyd.], Praha: NLN.

Levý, Jiří (1957) České theorie překladu, Praha: Státní nakladatelství krásné literatury, hudby a umění.

Lhotová, Kateřina (2015) Česká recepce prózy Michaila Bulgakova Osudná vejce [online]: https://is.cuni .cz/webapps/zzp/detail/150312. (access: 30. 3. 2019) Vedoucí práce: Stanislav Rubáš.

Opelík, Jiří (ed.) (2000) Lexikon české literatury: osobnosti, díla, instituce. [Díl] 3, M-̌̆. Svazek I, M-O, 1. vyd., Praha: Academia.

Rameš, Václav (2005) Slovník pro historiky a návštěvníky archivů, Praha: Libri.

Rejzek, Jiř́ (2015) Český etymologický slovník, 3., dopl. vyd., Praha: Leda.

Středová, Kateřina (2019) 'Critical archival research in Translation Studies: when a translation scholar becomes an archivist-researcher', Mutatis Mutandis, 12(2): 498-516.

Urbánková, Nad’a (2003) 'Jak správně citovat aneb Komentár k ČSN ISO 690', Věstník Asociace muzeí a galerií České republiky, 4(4): 25-36: https://www.cz-museums.cz/UserFiles/file/propedeutika /zakladni\%20kurs/ISO\%20690.pdf (access: 30. 3. 2019).

Vyhláška č. 645/2004 Sb., novelizovaná vyhláškou č. 213/2012 Sb.

Zach, Aleš (1976) Ediční dílo Kamilly Neumannové: bibliografický soupis k 100. výročí jejího narození a 20. výročí úmrtí. Praha: Památník národního písemnictví.

Zákon č. 499/2004 Sb., o archivnictví a spisové službě, ve znění zákona č. 250/2014 Sb.

\section{PEЗЮME}

Архивная среда мало известна большинству транслатологов, именно поэтому цель данной статьи - донести информацию о работе с архивными текстами и методах их обработки тем, кто заинтересован в изучении подобных материалов. Во введении представлены источники информации, которые исследователь может использовать при изучении истории перевода. Архивные материалы могут служить источником знаний о методах работы, использовавшихся в прошлом - как с точки зрения перевода, так и публикации книг. В то же время они позволяют изучать переводы и их авторов в более широком контексте.

В первом и втором блоках представлена система архивации в Чешской Республике и положения законов, регулирующие деятельность архивов и работу в них. Цель этих разделов обзор прав и обязанностей исследователя и представление процессов, происходящих в архивах, для лучшего понимания и облегчения ориентации в организации коллекций.

В третьем тематическом блоке описываются методы работы с архивными источниками, в первую очередь анализ и интерпретация. В процессе анализа источников необходимо сначала определить их подлинность (то есть, не являются ли они фальсификатом), проверить их датировку и авторство, только тогда можно начать работать с содержащейся в них 
информацией, поместить ее в контекст других документов и предыдущих знаний по данной теме. В ходе анализа и интерпретации транслатолог может также эффективно пользоваться своими навыками в области текстового анализа, однако необходимо помнить о том, что он работает с историческими материалами, а не с опубликованными текстами: интерпретировать источники необходимо в контексте того времени и не дополнять их сторонней информацией.

\section{Kateřina Středová}

Ústav translatologie, Filozofická fakulta Univerzity Karlovy, Praha

stredova.katerina@gmail.com 